\title{
Male Germ Cell Development in Humans
}

\author{
Jan-Bernd Stukenborg ${ }^{\mathrm{a}}$ Kristín Rós Kjartansdóttir ${ }^{\mathrm{a}} \quad$ Ahmed Reda $^{\mathrm{a}}$ \\ Eugenia Colon ${ }^{\mathrm{a}, \mathrm{b}}$ Jan Philipp Albersmeier ${ }^{\mathrm{a}}$ Olle Söder $^{\mathrm{a}}$ \\ a Pediatric Endocrinology Unit, Department of Women's and Children's Health, and ${ }^{\text {b}}$ Department of Clinical \\ Pathology and Cytology, Karolinska Institutet and University Hospital, Stockholm, Sweden
}

\section{Key Words}

Testis · Germ cells · Spermatogonial stem cells · Gonads ·

Spermatogenesis

\begin{abstract}
Background: Germ cells are unique cells that possess the ability to transmit genetic information between generations. Detailed knowledge about the molecular and cellular mechanisms determining the fate of human male germ cells still remains sparse. This is partially due to ethical issues limiting the access to research material. Therefore, the mechanisms of proliferation, differentiation and apoptosis of human male germ cells still remain challenging study objectives. Methods: This review focuses on using English articles accessible in PubMed as well as personal files on the current knowledge of the molecular and cellular mechanisms connected with human testicular germ cell development, maturation failure and the possibility of fertility preservation in patients in whom there is a risk of gonadal failure. However, since rodents, particularly mice, offer the possibility of studying germ cell development by use of genetic modification techniques, some studies using animal models are also discussed. Conclusion: This mini review focuses on the current knowledge about male germ cells. However, the reader is referred to two previous mini reviews focusing on testicular somatic cells, i.e. on Sertoli cells and Leydig cells.
\end{abstract}

(c) 2013 S. Karger AG, Basel

\section{KARGER}

E-Mail karger@karger.com

www.karger.com/hrp

\section{Introduction}

\section{Human Male Germ Cell Development: Prenatal}

The establishment of the human male germ cell lineage starts during embryogenesis at 4 weeks' gestation [1]. Studies on mice have shown that primordial germ cells (PGC) originate from the proximal epiblast in the yolk sac in response to bone morphogenetic protein stimulation from the nearby visceral endoderm and extraembryonic ectoderm [2]. However, little is known about the origin of human PGC, though it is believed to be similar to that in the mouse. Recently, it has been shown that bone morphogenetic protein 4 enhances human PGC propagation in vitro [3]. It has long been believed that the PGC gather outside the embryo at the yolk sac wall and then migrate through the hindgut to the genital ridge, which later will become the primitive gonad [4]. The PGC express KIT/c-KIT receptor tyrosine kinase, and the surrounding somatic cells express its ligand, KITLG/SCF/ STEEL. The interaction between KIT and KITLG has been suggested to support the migration and survival of PGC $[5,6]$. However, recent reports have indicated that PGC migrate very little and their migration from the yolk sac to the genital ridge is aided by hindgut expansion and

\section{J.-B.S. and K.R.K. contributed equally to this study.}

Olle Söder, MD, PhD (ESPE Member)

Pediatric Endocrinology Unit, Department of Women's and Children's Health Karolinska Institutet and University Hospital

Karolinskavägen, Solna, SE-17176 Stockholm (Sweden)

E-Mail olle.soder@ki.se 
growth movements $[7,8]$. Furthermore, it was proposed that human PGC move together with autonomic nerve fibers from the dorsal mesentery to the developing gonad $[9,10]$. This hypothesis is supported by the fact that the enteric nervous system of the mid- and hindgut expresses KITLG and therefore could facilitate migration [11]. However, further studies are needed in order to clarify the exact process of PGC migration.

PGC arise from embryonic cells that already have been partly committed to a somatic fate [12]. This means that their genome has already undergone DNA methylation and histone modifications, both of which are epigenetic marks that can regulate gene expression without changing the DNA sequence. During PGC proliferation and relocalization, global DNA methylation erasure occurs [13]. Now the genome is like a blank page and ready for sex-specific de novo DNA methylation. In the male, this methylation occurs in mitotically inactive cells before birth and in growing oocytes in females after birth. In this way the genome of the developing germ cells get distinct methylation profiles of sperm and oocytes [14].

Molecular markers to identify germ cells at various stages of their development are highly warranted, and search for such markers is an active research area. The nascent and relocalizing human PGC express markers such as POU5F1/OCT4, GAGE, MAGE-A4 and KIT [9], while mouse PGC have also been shown to express $\operatorname{Prdm1/}$ Blimp, Dppa3/Stella, Ifitm3/Fragilis and Tnap/Alpl/Ap [15]. In humans, by gestational week 4-6 the PGC enter and colonize the developing gonad located in the genital ridge, and from then on are referred to as 'gonocytes' [16]. Gonocytes express genes such as MAGE-A4, DAZ, KIT, PLAP, POU5F1, TFAP2C/AP-2 $\gamma$ and UTF1 [17, 18]. $D D X 4 / V A S A$ is the most widely used marker for germ cells and it is expressed from the gonocyte stage and throughout the whole differentiation process [19].

The decision of gonocytes to enter the female or male germ cell pathway is influenced by the somatic compartment surrounding the germ cells. In males, mesenchymal, Sertoli and Leydig cells are crucial for the formation of the male gonadal paracrine and endocrine interactions (e.g. inhibin B and testosterone) $[20,21]$. The initiation of the male path of sexual development is dependent on the activation of several genes such as DHH, FGF9, M33, DMRT1, AMH, SRY and SOX9 [16, 22].

\section{Human Male Germ Cell Development: Postnatal}

After the gonocytes have been directed to the male or female path, they either initiate meiosis (female path) or not (male path). Concentrating on the male pathway, the gonocytes migrate to the basal membrane and become spermatogonia postnatally after approximately 6 months (fig. 1) [23]. By reaching the basal membrane, the gonocytes lose their status of pluripotency, which is depicted by changes in their morphology as well as gene expression profiles (e.g. POU5F1, NANOG, TFAP2C and KIT) [24]. As discussed below in the next paragraph, this change in expression levels, mainly for POU5F1 and NANOG, is influenced in testicular germ cell tumors (TGCT) and might be crucial for the survival of these malignant cells within the testis [25]. In contrast to human, spermatogonial stem cells (SSC) described in rodents do express markers such as POU5F1 or TFAP2C throughout their life [26-30].

Normal spermatogenesis is a complex growth and maturation process encompassing three distinct stages: (1) mitotic proliferation and maturation of spermatogonia; (2) meiotic cleavage to form haploid cells, and (3) final maturation into elongated spermatids and spermatozoa (spermiogenesis). In quantitative terms, spermatogenesis starts in early puberty and is clinically recorded as an increased testicular volume. In humans, spermatogonia can be divided into at least two subtypes: (1) undifferentiated (type $A_{\text {dark }}$ and $A_{\text {pale }}$; fig. 1) and (2) differentiated (type B). Type A spermatogonia differentiate and form type B spermatogonia, which undergo mitotic proliferation until puberty, when meiosis is initiated $[16,31]$. A multitude of genes are related to the different types of spermatogonia (fig. 2), and many of those have been suggested as potential SSC markers [16, 32]. Recently, isolation of human putative SSC has been performed by selecting GPR125-positive cells coexpressing ITGA6, THY1 and GFRa1 [33].

The meiotic process gives rise to haploid spermatocytes and can be grouped into preleptotene, leptotene, zygotene, pachytene and diplotene stages. After the second meiotic division, haploid round spermatids are formed, which turn into elongated spermatids during spermiogenesis, which is a morphogenic process without further proliferation [34]. The whole process of human spermatogenesis takes 74 days and gives rise to 16 spermatids, if at full efficacy, from each SSC [35]. The sperm is finally released into the lumen of the seminiferous tubules and transferred to the epididymis for final maturation.

Since the processes of spermatogenesis and spermiogenesis are highly complex, a failure in any crucial gene is immediately affecting the outcome of both. Below we will focus on genes expressed by male germ cells related to dysfunctional spermatogenesis. 


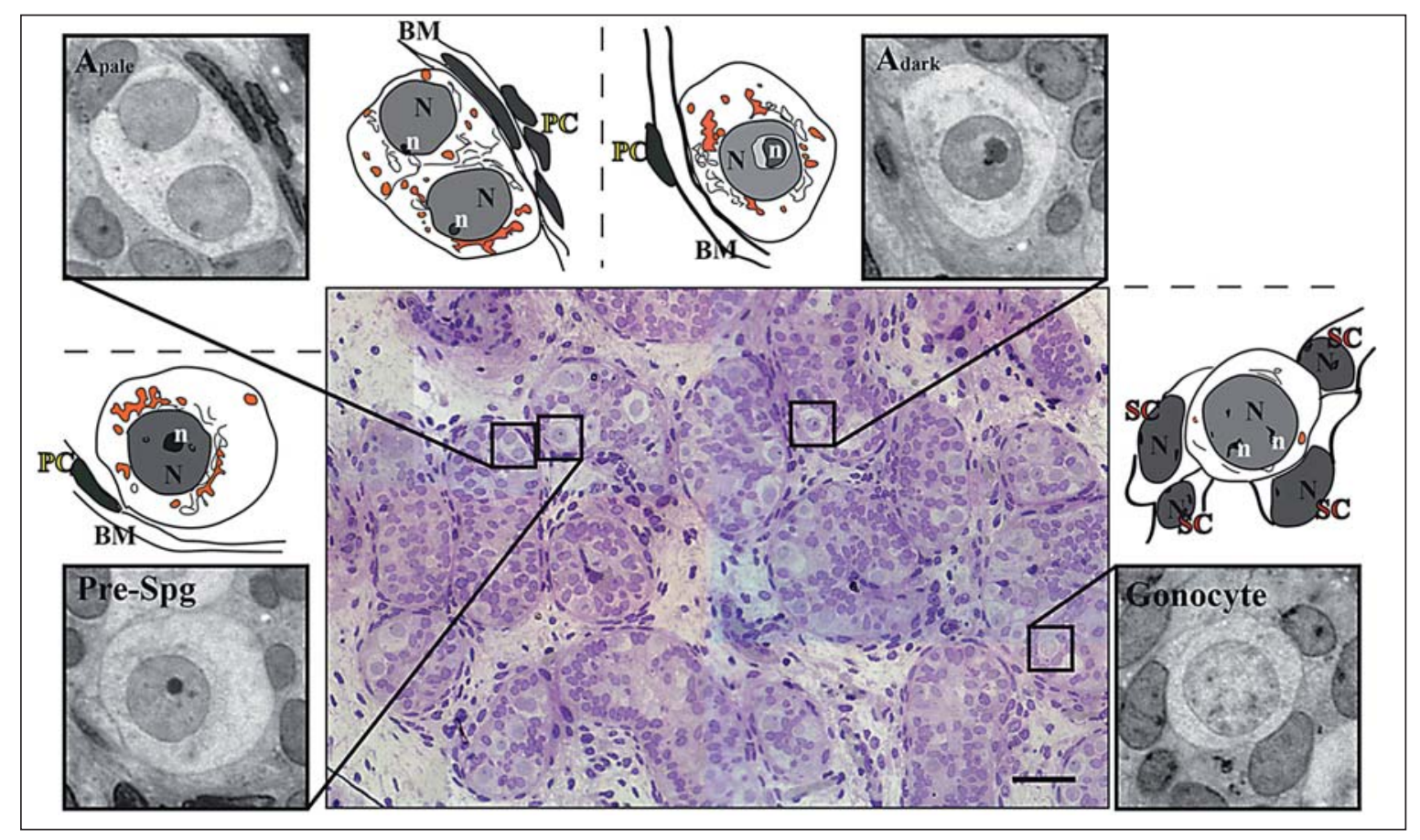

Fig. 1. Histological overview of early human germ cells. Different germ cells [gonocytes; prespermatogonia (Pre-Spg); $A_{\text {dark }}$ spermatogonia; $A_{\text {pale }}$ spermatogonia] are shown in a cross-section of seminiferous tubules from a 9-month-old boy and highlighted at higher magnification and as cartoons. According to the literature, the cell types can be characterized as follows. Gonocytes: located in the lumen; cells are roughly spherical with a high nucleocytoplasmic ratio; nuclei in the center; binuclear forms are occasionally seen (preserved without evidence of degeneration); nucleoli have characteristic filamentous structure (uniform electron density) and are usually not attached to the inner nuclear membrane; double nuclear membrane has no unusual features; cytoplasm contains 2 types of mitochondria (one with parallel cristae and another with dilated vesicular cristae); some of the mitochondria are connected to the outer nuclear membrane [94]. Prespermatogo$\mathrm{nia} /$ fetal spermatogonia: located at the basal membrane; frequently chromatid body in cytoplasm; large cell body; round-to-oval nucleus (about twice as large as that of Sertoli cells); large nucleolus in the middle of the nucleus (consisting of loose reticular substance and 2-3 amorphous bodies); chromatin is distributed over the entire nucleus in form of fine granules; large mitochondria connected with intermitochondrial substance (mainly tubule type, but also crista type); Golgi complex is concentrically located around the

\section{Reasons for Failure of Human Male Germ Cell Development}

There are many different reasons for failure of male germ cell development. Overall, mutations in genes related to PGC, gonocytes and spermatogonia are often accompanied by tumor formation, early spermatogenic ar- nucleus; chromatid bodies are frequently observed in the vicinity of the nucleus [95-97]. $A_{\text {dark }}$ spermatogonia: located at the basal membrane; characteristic 'lighter zone' (rerarification) generally located in the middle of the nucleus; peripherally located nucleoli, rarely connected to the nuclear membrane; crista-type mitochondria are connected to the nuclear membrane and often to each other by intermitochondrial substance (cement); rougher endoplasmic reticulum concentrically around the nucleus than $A_{\text {pale }}$ spermatogonia; ribosomes, microtubules and glycogen granules in the cytoplasm; 'crystalloid of Lubarsch' (1896) in the vicinity of the nucleus $[95,98]$. A pale spermatogonia: located at the basal membrane; 2-4 times bigger than an $S_{a}$ Sertoli cell (developed from fetal Sertoli cells directly after birth and roughly twice as big as an adult erythrocyte); excentrically located round or polygonal nucleus; bleb formation can be observed in the nucleus; fine and homogenously distributed chromatin; 1-3 nucleoli attached to the nuclear membrane; no mitochondria are attached to the nucleus; cytoplasm is of fine granular type; occasionally large vacuoles in the cytoplasm; crista-type mitochondria; slightly developed Golgi apparatus; ribosomes, microtubules and glycogen granules in the cytoplasm; 'crystalloid of Lubarsch' (1896) in the vicinity of the nucleus $[95,98,99]$. $\mathrm{BM}=$ Basal membrane; $\mathrm{N}=$ nucleus; $\mathrm{n}=$ nucleolus; $\mathrm{SC}=$ Sertoli cell; $\mathrm{PC}=$ peritubular cell. 


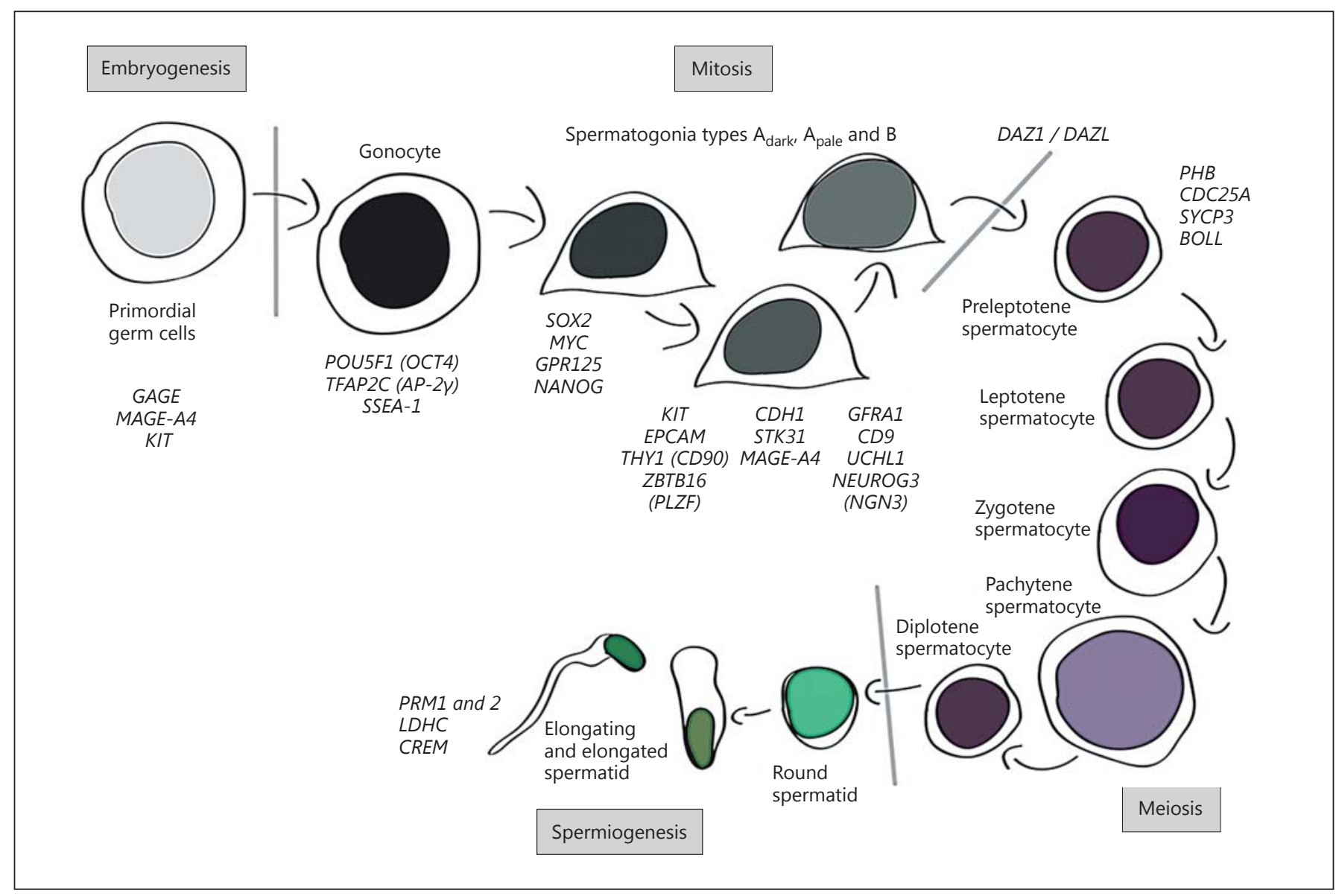

Fig. 2. Schematic overview of genes expressed during different stages of human male germ cell development.

not yet produce mature sperm and therefore are not able to supply mature gametes for cryopreservation before starting oncological treatment [38].

\section{Testicular Germ Cell Tumors}

The incidence of TGCT is $1 \%$ of all cancers in men, and $95 \%$ of those arise in men between 15 and 34 years of age. Interestingly, the precursor cells for TGCT, carcinoma in situ or gonadoblastoma cells seem to arise during fetal life and are silent until they transform into TGCT cells later in life [24].

TGCT are known to be related to mutations in several genes including KITLG, SPRY4, BAK1, TERT, DMRT1 and ATF7IP [39]. Detection of these malignant cells on the protein level can be achieved by showing positive expression mainly for POU5F1, PLAP, KIT, TFAP2C/AP$2 \gamma$ and NANOG [25]. Thus, these cells express many markers which have been described for early germ cells like gonocytes and PGC $[24,25]$. Recent studies are in line with previous ones, demonstrating the important role of KITLG and DMRT1 gene alterations as main factors involved in TGCT formation [40, 41]. As a third important player in TGCT formation, TSPY has to be mentioned. TSPY is expressed in spermatogonia in the healthy adult testis, but in immature germ cells in testes with TGCT [24]. TSPY has no functional homolog in mice and might thereby explain why no type II TGCT (classic testicular seminoma, dysgerminoma as well as various types of nonseminoma/nondysgerminoma) has been described in these animals so far [42].

Even if the detailed physiological role of TSPY is not totally understood, an overexpression seems to contribute to the survival and proliferation of germ cells, even in an nonoptimal environment [43]. This antiapoptotic effect has also been described for POU5F1 and KITLG [10, $24,44]$. However, POU5F1 is mainly expressed in early 
germ cells up to the stage of gonocytes, whereas TSPY is expressed mainly in early spermatogonia when gonocytes have reached the basal membrane and formed prespermatogonia $[18,45]$. Therefore, a double expression of POU5F1 and TSPY in germ cells at the basal membrane of the seminiferous cord/tubule might be a strong indicator for malignant cell development in the testis [46, 47]. These findings are also in line with a recent study by Som et al. [48], which suggests that the origin of seminoma is more likely in the undifferentiated than in a dedifferentiated germ cell. In addition to the germ cell origin, the influence of paracrine and endocrine pathways on the development of abnormal functions of somatic and germ cells in the testis has been discussed in several studies and a delayed function has been associated with the formation of testis cancer $[24,49,50]$. A reduced androgen production might act via the Sertoli cells on the germ cells and be the reason for the increased risk of patients with androgen insensitivity syndrome to develop TGCT [24, 25, 50].

\section{Spermatogenic Arrest}

Spermatogenic arrest is defined as an interruption to male germ cell development at any stage before complete maturation. Reasons for spermatogenic arrest are primarily genetic or a result of secondary influences from other diseases (e.g. severe liver or kidney insufficiency, sickle cell anemia), or iatrogenic (radiation, chemotherapy or certain antibiotics) [38]. To date there are no therapies available for cure of complete (azoospermia) or partial (oligoasthenoteratozoospermia) arrest of spermatogenesis. As mentioned before, impairment or failure of even one gene related to germ cell differentiation may cause spermatogenic arrest. This arrest can be observed at different developmental levels (spermatogonia, primary or secondary spermatocytes and round spermatids) and can be roughly defined as premeiotic, meiotic and postmeiotic spermatogenic arrest (fig. 3).

At the start of spermatogenesis, genes of importance for SSC renewal and differentiation are often regulated by Sertoli cells $[16,21]$. Some of those which are involved in these regulations and expressed in human SSC are GFR $\alpha 1$, THY1/CD90, PLZF, MAGE-A4 and GPR125 [32]. Failure related to these and to genes expressed by Sertoli cells (e.g. ERM) has been studied in mice, and it results in spermatogonial arrest or Sertoli-cell-only syndrome [51].

In mice, $m U t p 14 b$, an $\mathrm{X}$-linked gene, is expressed from the level of zygotes up to round spermatids [52]. Failure of this gene causes a spermatogonial arrest after the first wave of spermatogenesis. A similar spermatogenic failure is observed in juvenile spermatogonial depletion (jsd) mice mutants $[53,54]$. This mutation is causing spermatogonial arrest at the level of type A spermatogonia, after the first wave of spermatogenesis in mice. From 4 to 20 weeks after birth, these animals show increased levels of follicle-stimulating hormone (FSH) but otherwise remain endocrinologically normal after 1 year.

In humans, BOULE, a member of the DAZ family, regulates the translation of $C D C 25$ [55] and was first identified in azoospermic men with Y-chromosomal deletion [56]. Together with cyclin $\mathrm{B}, C D C 25$ is driving meiosis as a maturation factor, and nonfunctional CDC25 results in disrupted spermatogenesis [57]. Genes of the DAZ family are expressed by differentiated spermatogonia type $B$, preleptotene and zygotene spermatocytes. In rats, $D A Z$ is involved in early stages of spermatogonial differentiation, while $D A Z L$ is connected to early spermatogenesis as well as the maturation of elongated spermatids during spermiogenesis [58].

Another main player is CREM, a gene of importance for the formation of haploid cells and therefore for the completion of spermatogenesis. CREM expression is modulated by FSH and GDNF, and a null mutation is causing spermatogenic arrest at the stage of round spermatids [59]. However, a deficiency of CREM specifically in Sertoli cells is not related to spermatogenic arrest.

After meiosis, disintegration of histones and the integration of protamines are crucial for the maturation process of the spermatozoa and are performed by the transition protein. Mutations in the transition protein influence the condensation of chromatin, causing breaks in the DNA structure of late spermatozoa.

Inhibin B has been described as an early indicator of testicular damage [60]. An early postnatal increase in inhibin B correlates with the activation of the hypothalamic-pituitary-gonadal axis and seems to parallel the changes in testosterone and luteinizing hormone levels. The highest levels of inhibin B are found at the age of 3 months postnatally during mini-puberty [61]. During puberty, inhibin B reflects Sertoli cell proliferation and FSH action. After completion of Sertoli cell differentiation, the levels of inhibin B decrease and remain at low levels. Changes in inhibin B after puberty are related to changes in germ cell proliferation. Here, the androgen receptor (AR) might be the driving force [60]. AR is not expressed in germ cells, but a lack of AR in Leydig cells has a major influence on the steroidogenic function and results in a spermatogenic arrest at the stage of round spermatids. In terms of spermatogenic outcome, inhibin B directly cor- 


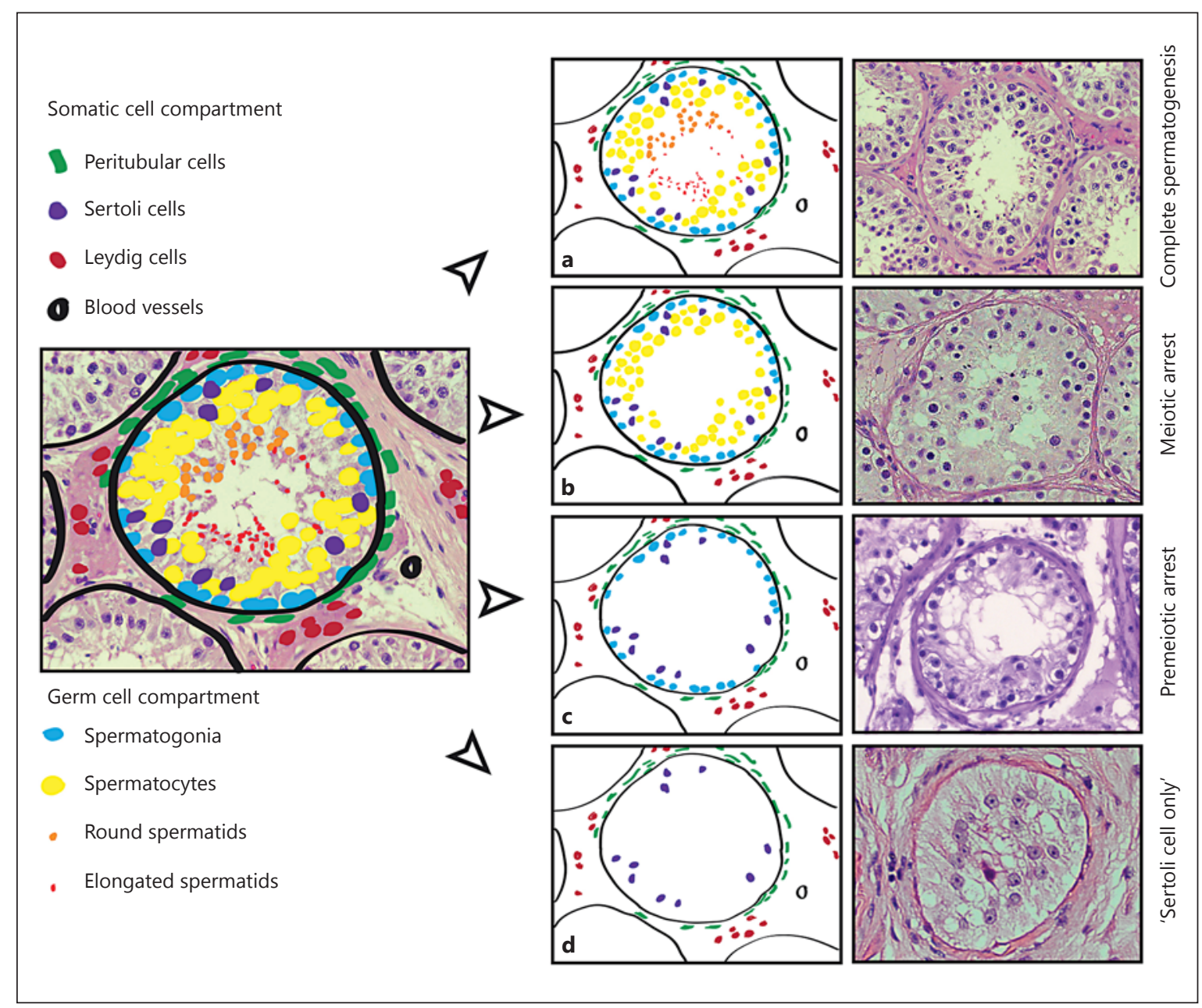

Fig. 3. Schematic overview of different stages in differentiation of human spermatogenesis: complete spermatogenesis (a), meiotic arrest (b), premeiotic arrest (c) and 'Sertoli cell only' (d). Different cell types, including cells of the germ and somatic cell compartments, present in the healthy adult testis are shown in a schematic overview on the left side (color code). Impairments of spermatogenesis are shown schematically in the middle column of the figure. Reference histological samples, stained for periodic acidSchiff reagent, for the different types of spermatogenesis are shown on the right side of the figure next to the schematic overviews. relates with sperm counts [62]. In addition to inhibin B, AMH is another crucial factor for Sertoli cell maturation, testicular formation and germ cell differentiation [49]. $\mathrm{AMH}$ is a dimeric glycoprotein hormone which belongs to the transforming growth factor- $\beta$ super family. During gonadal development, $A M H$ is one of the first genes expressed by Sertoli cells $[49,63]$ and is maintained as long as they stay in their immature status until puberty. A recent study by Dennis et al. [64] demonstrated that serum levels of AMH reflect the number of cells producing AMH. Therefore, AMH may be used as a marker of gonadal developmental status in humans.

\section{Germ Cell Consequences of Cryptorchidism}

With a prevalence in full-term newborns of $1-3 \%$, cryptorchidism is the most common congenital malformation in boys [37]. Well-recognized consequences of cryptorchidism include impairment of germ cell maturation, subsequent infertility in adulthood as well as a higher risk for development of TGCT [65]. As early as 6 months of age, a reduction in germ cell numbers starts, dependent on the position of the testes. In general, the higher the testicular position at the time of treatment, the fewer the number of germ cells $[66,67]$. A lack of germ cells is an important predictor of future infertility and can be identified by testicular biopsy, taken at the time of or- 
chiopexy [68]. The incidence of azoospermia in unilateral cryptorchidism is $13 \%$, whereas an increase up to $89 \%$ in untreated bilateral cryptorchidism was described [69]. However, due to the rarity of spontaneous descent after 1 year of age and the possible improvement in fertility that early intervention may confer, cryptorchidism should be treated before the patient is 1 year old $[65,67$, 70]. Furthermore, to preserve fertility in patients with bilateral orchiopexy, freezing of sperm or testicular tissue with preserved spermatogenesis has also been suggested [71].

\section{Germ Cells in Klinefelter Syndrome (KS)}

The estimated prevalence of KS in the general male population is around $0.2 \%$ [72]. In spite of the wide variability in clinical appearance, patients with KS suffer from absolute or relative hypergonadotropic hypogonadism as well as impaired spermatogenesis. During childhood, boys with KS have lower testicular volumes compared with age-matched controls [72]. In KS patients, the growth of the testes is increasing temporarily until midpuberty. After midpuberty it declines, and low serum testosterone as well as elevated gonadotropin levels can be observed [73]. It has been described that spermatogenesis in these patients is often arrested at the level of spermatogonia or early spermatocytes. Spermatogonia seem to be hindered to enter the meiotic pathway and undergo apoptosis at the onset of puberty [74]. A gradual deterioration in seminiferous tubules can be observed over time. This is accompanied by tubular hyalinization as well as Leydig cell hyperplasia, which is characteristic of testes in adult KS patients. Isolated foci of spermatogenesis can exist in the testes of KS patients. Therefore, successful pregnancies resulting from rare ejaculated sperm in the semen of men with KS have been reported $[75,76]$. Recent studies recommend early sperm and/or semen retrieval or, for prepubertal patients, cryopreservation of testicular tissue, due to the progressive decline in steroidogenic and spermatogenic functions during puberty in KS patients [77-79]. Attempts at surgical sperm retrieval were reported to be successful in up to $66 \%$ of men included in a study by Ramasamy et al. [80]. In combination with advanced assisted reproduction technology (ART), these sperm retrieval rates have improved the ability of KS patients to father their own biological children. However, no generally accepted recommendations for cryopreservation of testicular tissue in KS adolescents exist so far.

\section{Fertility Preservation}

It is well recognized that germ cells are difficult to culture in vitro and are sensitive to conditions that apply outside the gonadal microenvironment. However, methods for retrieving, processing and maturing germ cells are highly warranted for clinical purposes. Pediatric cancer patients exposed to gonadotoxic therapy are an increasing group which attracts such attention in order to preserve their future gonadal function.

\section{Methods for Preserving Male Germ Cells}

Postpubertal males who produce fully mature sperm can cryopreserve their semen with a possibility to father children upon desire later in life by in vitro fertilization. Young prepubertal boys do not produce mature sperm and thus do not have the option of cryopreserving sperm [38]. Prepubertal patients can be offered testicular biopsy which contains SSC. Potentially, the immature testicular tissue or isolated SSC can be matured either in vitro or by placing them back into the normal somatic microenvironment (to be discussed below). The idea is that these cells can later in life be used for in vitro fertilization and give these patients the option of fathering their own biological children. Since testicular tissue or isolated germ cells need to be stored for a long time, cryopreservation techniques need to be optimized. Currently, one of the procedures for cryopreservation used most often is to add ethylene glycol and dimethyl sulfoxide together with a slow freezing program [38].

\section{Methods for Maturation of Male Germ Cells}

Major efforts have been put into optimizing in vivo and in vitro methods for maturation of immature germ cells, but these techniques still remain experimental (fig. 4). For the in vivo methods, the immature testicular tissue or SSC could be transplanted back to the patient after cancer treatment, but in such a case there is a potential risk of introducing cancer cells back to the patient [81]. Transplanting the tissue or the isolated SSC to other animal species for maturation is also an option, but then there is a potential risk of introducing the germ cells to xenogenic tissue hosting unknown viruses such as retroviruses. Therefore, such a methodology would presently not be considered acceptable in clinical practice. For the in vitro methods, the SSC could be differentiated in a monolayer on a supporting feeder layer or on extracellular matrixes $[82,83]$. Also, it has been reported that premeiotic germ cells from mice can be differentiated in a soft agar culture system where the cells have $3 \mathrm{D}$ support 


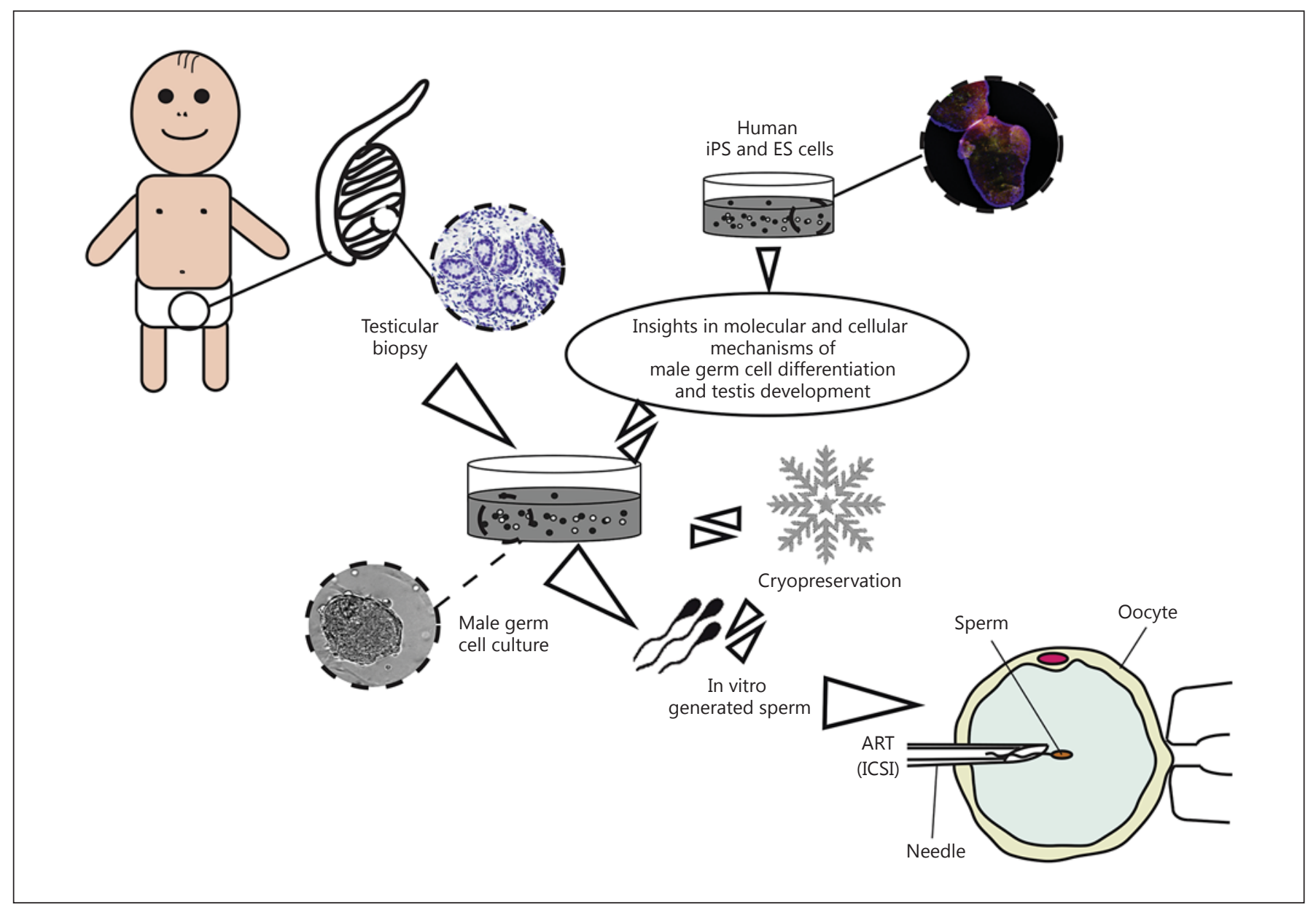

Fig. 4. Strategies to explore molecular and cellular mechanisms important for human spermatogenesis and needed for the establishment of an in vitro system to differentiate early male germ cells into mature sperm for potential use of ART in the future. These experimental strategies involve cultures of human induced pluripotent stem (iPS) and human embryonic stem (ES) cells as well as testicular cells obtained from biopsies of prepubertal testes. ICSI = Intracytoplasmic sperm injection.
$[84,85]$. Another promising system currently showing a successful differentiation of early germ cells into mature sperm in mice is the organ culture [86, 87].

All of these methods are still technically suboptimal and need to be further improved in order to be employed for clinical purposes. This optimization research is difficult due to limited access to human prepubertal testicular material. Further, much research of this kind is still done on animal models, which is problematic as there are species differences. A novel and promising strategy is to employ human embryonic stem cells (hESC) and human induced pluripotent stem cells (hiPSC) in order to try to optimize in vitro differentiation [88-90]. These stem cells are pluripotent but originate from different sources; hESC are derived from the inner cell mass of an embryo at the blastocyst stage, while hiPSC are generated by reprogramming somatic cells to a pluripotent stage by using factors of importance for pluripotency, e.g. the Yamanaka factors (POU5F1, KLF4, SOX2 and MYC) [9193]. In theory, these pluripotent stem cells are able to differentiate in vitro into all the different cell types of the body, including germ cells if the right culture and differentiation methods are found.

\section{Stem Cell Approach to Mature Germ Cells to Rescue Future Fertility}

Because research material from prepubertal boys is sparse, hESC and hiPSC would be ideal for optimizing an in vitro model for differentiation of immature germ cells into mature sperm. Being able to differentiate hESC and 
hiPSC as well as immature germ cells in vitro would help in understanding the basics of germ cell development as well as aid in optimizing a protocol for fertility preservation (fig. 4). Furthermore, if possible, it would be a huge breakthrough if hiPSC obtained from an infertile male could be differentiated into morphologically, genetically and epigenetically normal and functional spermatozoa. These hiPSC would be patient specific, and thus immune rejection and graft-versus-host reaction could be avoided. In theory, these spermatozoa could be used in combination with advanced ART.

\section{Concluding Remarks}

Germ cells are the most fundamental cells in life, complicated and fragile. Increasing knowledge has been obtained about the control of proliferation and differentia- tion of human male germ cells, but a lot yet remains unknown. Techniques are now rapidly developing to expand and mature germ cells in vitro, and such approaches have produced apparently normal offspring in experimental animal models. Although there are still ethical, safety and efficiency concerns with humans, we anticipate that it will not take long until such methods, combined with advanced ART, are introduced at highly specialized medical centers.

\section{Acknowledgements}

Original work cited in this study was supported by the Swedish Research Council, Finnish Academy, Swedish Children's Cancer Fund, Lindhés Advokatbyrå and Emil and Wera Cornells Stiftelsen. J.-B.S. is supported by the Deutsche Forschungsgemeinschaft (DFG grant No. STU 506/3-1).

\section{References}

1 Fujimoto T, Miyayama Y, Fuyuta M: The origin, migration and fine morphology of human primordial germ cells. Anat Rec 1977; 188:315-330.

- 2 Ying Y, Qi X, Zhao GQ: Induction of primordial germ cells from murine epiblasts by synergistic action of BMP4 and BMP8B signaling pathways. Proc Natl Acad Sci USA 2001;98: 7858-7862.

-3 Hiller M, Liu C, Blumenthal PD, Gearhart JD, Kerr CL: Bone morphogenetic protein 4 mediates human embryonic germ cell derivation. Stem Cells Dev 2011;20:351-361.

4 Raz E: Guidance of primordial germ cell migration. Curr Opin Cell Biol 2004;16:169173.

5 Matsui Y, Zsebo KM, Hogan BL: Embryonic expression of a haematopoietic growth factor encoded by the SI locus and the ligand for ckit. Nature 1990;347:667-669.

6 Richardson BE, Lehmann R: Mechanisms guiding primordial germ cell migration: strategies from different organisms. Nat Rev Mol Cell Biol 2010;11:37-49.

7 Freeman B: The active migration of germ cells in the embryos of mice and men is a myth. Reproduction 2003;125:635-643.

8 Hara K, Kanai-Azuma M, Uemura M, Shitara $\mathrm{H}$, Taya C, Yonekawa H, Kawakami H, Tsunekawa N, Kurohmaru M, Kanai Y: Evidence for crucial role of hindgut expansion in directing proper migration of primordial germ cells in mouse early embryogenesis. Dev Biol 2009;330:427-439.
\9 Møllgård K, Jespersen A, Lutterodt MC, Yding Andersen C, Høyer PE, Byskov AG: Human primordial germ cells migrate along nerve fibers and Schwann cells from the dorsal hind gut mesentery to the gonadal ridge. Mol Hum Reprod 2010;16:621-631.

10 Mamsen LS, Brøchner CB, Byskov AG, Møllgård $\mathrm{K}$ : The migration and loss of human primordial germ stem cells from the hind gut epithelium towards the gonadal ridge. Int J Dev Biol 2012;56:771-778.

11 Høyer PE, Byskov AG, Møllgård K: Stem cell factor and c-Kit in human primordial germ cells and fetal ovaries. Mol Cell Endocrinol 2005;234:1-10.

12 Ohinata Y, Ohta H, Shigeta M, Yamanaka K, Wakayama T, Saitou M: A signaling principle for the specification of the germ cell lineage in mice. Cell 2009;137:571-584.

13 Sasaki H, Matsui Y: Epigenetic events in mammalian germ-cell development: reprogramming and beyond. Nat Rev Genet 2008; 9:129-140.

14 Smallwood SA, Kelsey G: De novo DNA methylation: a germ cell perspective. Trends Genet 2012;28:33-42.

-15 Sabour D, Araúzo-Bravo MJ, Hübner K, Ko K, Greber B, Gentile L, Stehling M, Schöler HR: Identification of genes specific to mouse primordial germ cells through dynamic global gene expression. Hum Mol Genet 2011;20: 115-125.

16 Stukenborg JB, Colón E, Söder O: Ontogenesis of testis development and function in humans. Sex Dev 2010;4:199-212.
17 Waheeb R, Hofmann MC: Human spermatogonial stem cells: a possible origin for spermatocytic seminoma. Int J Androl 2011; 34:e296-e305, discussion e305.

18 Pauls K, Schorle H, Jeske W, Brehm R, Steger K, Wernert N, Büttner R, Zhou H: Spatial expression of germ cell markers during maturation of human fetal male gonads: an immunohistochemical study. Hum Reprod 2006;21: 397-404.

19 Castrillon DH, Quade BJ, Wang TY, Quigley C, Crum CP: The human VASA gene is specifically expressed in the germ cell lineage. Proc Natl Acad Sci USA 2000;97:9585-9590.

20 Svechnikov K, Landreh L, Weisser J, Izzo G, Colón E, Svechnikova I, Söder O: Origin, development and regulation of human Leydig cells. Horm Res Paediatr 2010;73:93-101.

- 21 Petersen C, Söder O: The Sertoli cell: a hormonal target and 'super' nurse for germ cells that determines testicular size. Horm Res 2006;66:153-161.

22 Barrionuevo FJ, Burgos M, Scherer G, Jiménez R: Genes promoting and disturbing testis development. Histol Histopathol 2012;27: 1361-1383.

23 Zivkovic D, Bica DT, Hadziselimovic F: Relationship between adult dark spermatogonia and secretory capacity of Leydig cells in cryptorchidism. BJU Int 2007;100:1147-1149, discussion 1149

24 Rajpert-de Meyts E: Developmental model for the pathogenesis of testicular carcinoma in situ: genetic and environmental aspects. Hum Reprod Update 2006;12:303-323. 
-25 Pleskacova J, Hersmus R, Oosterhuis JW, Setyawati BA, Faradz SM, Cools M, Wolffenbuttel KP, Lebl J, Drop SL, Looijenga LH: Tumor risk in disorders of sex development. Sex Dev 2010;4:259-269.

-26 Hou M, Stukenborg JB, Nurmio M, Andersson M, Toppari J, Söder O, Jahnukainen K: Ontogenesis of Ap- $2 \gamma$ expression in rat testes. Sex Dev 2011;5:188-196.

-27 Mitchell RT, Cowan G, Morris KD, Anderson RA, Fraser HM, McKenzie KJ, Wallace WH, Kelnar CJ, Saunders PT, Sharpe RM: Germ cell differentiation in the marmoset (Callithrix jacchus) during fetal and neonatal life closely parallels that in the human. Hum Reprod 2008;23:2755-2765.

-28 Pauls K, Jäger R, Weber S, Wardelmann E, Koch A, Büttner R, Schorle H: Transcription factor AP-2 $\gamma$, a novel marker of gonocytes and seminomatous germ cell tumors. Int J Cancer 2005;115:470-477.

-29 Lacham-Kaplan O: In vivo and in vitro differentiation of male germ cells in the mouse. Reproduction 2004;128:147-152.

-30 Dann CT, Alvarado AL, Molyneux LA, Denard BS, Garbers DL, Porteus MH: Spermatogonial stem cell self-renewal requires OCT4, a factor downregulated during retinoic acidinduced differentiation. Stem Cells 2008;26: 2928-2937.

-31 Ehmcke J, Wistuba J, Schlatt S: Spermatogonial stem cells: questions, models and perspectives. Hum Reprod Update 2006;12:275282.

32 Kolasa A, Misiakiewicz K, Marchlewicz M, Wiszniewska B: The generation of spermatogonial stem cells and spermatogonia in mammals. Reprod Biol 2012;12:5-23.

-33 He Z, Kokkinaki M, Jiang J, Dobrinski I, Dym M: Isolation, characterization, and culture of human spermatogonia. Biol Reprod 2010;82: 363-372.

34 Clermont Y: Kinetics of spermatogenesis in mammals: seminiferous epithelium cycle and spermatogonial renewal. Physiol Rev 1972;52: 198-236.

-35 Amann RP: The cycle of the seminiferous epithelium in humans: a need to revisit? J Androl 2008;29:469-487.

-36 Jorgensen PB, Kjartansdóttir KR, Fedder J: Care of women with XY karyotype: a clinical practice guideline. Fertil Steril 2010;94:105113.

-37 Petersen C, Zips D, Krause M, Schöne K, Eicheler W, Hoinkis C, Thames HD, Baumann M: Repopulation of FaDu human squamous cell carcinoma during fractionated radiotherapy correlates with reoxygenation. Int J Radiat Oncol Biol Phys 2001;51:483-493.

>38 Jahnukainen K, Stukenborg JB: Clinical review: present and future prospects of male fertility preservation for children and adolescents. J Clin Endocrinol Metab 2012;97:43414351.

-39 Nallu A, Mannuel HD, Hussain A: Testicular germ cell tumors: biology and clinical update. Curr Opin Oncol 2013;25:266-272.
40 Kanetsky PA, Mitra N, Vardhanabhuti S, Vaughn DJ, Li M, Ciosek SL, Letrero R, D’Andrea K, Vaddi M, Doody DR, Weaver J, Chen C, Starr JR, Håkonarson H, Rader DJ, Godwin AK, Reilly MP, Schwartz SM, Nathanson KL: A second independent locus within DMRT1 is associated with testicular germ cell tumor susceptibility. Hum Mol Genet 2011;20:3109-3117.

41 Ferlin A, Pengo M, Pizzol D, Carraro U, Frigo AC, Foresta C: Variants in KITLG predispose to testicular germ cell cancer independently from spermatogenic function. Endocr Relat Cancer 2012;19:101-108.

42 Oosterhuis JW, Looijenga LH: Testicular germ-cell tumours in a broader perspective. Nat Rev Cancer 2005;5:210-222.

43 Lau YF, Li Y, Kido T: Gonadoblastoma locus and the TSPY gene on the human Y chromosome. Birth Defects Res C Embryo Today 2009;87:114-122.

44 Kehler J, Tolkunova E, Koschorz B, Pesce M, Gentile L, Boiani M, Lomelí H, Nagy A, McLaughlin KJ, Schöler HR, Tomilin A: Oct4 is required for primordial germ cell survival. EMBO Rep 2004;5:1078-1083.

45 Honecker F, Stoop H, de Krijger RR, Chris Lau YF, Bokemeyer C, Looijenga LH: Pathobiological implications of the expression of markers of testicular carcinoma in situ by fetal germ cells. J Pathol 2004;203:849-857.

46 Cools M, Drop SL, Wolffenbuttel KP, Oosterhuis JW, Looijenga LH: Germ cell tumors in the intersex gonad: old paths, new directions, moving frontiers. Endocr Rev 2006;27:468484.

47 Palma I, Garibay N, Pena-Yolanda R, Contreras A, Raya A, Dominguez C, Romero $M$, Aristi G, Queipo G: Utility of OCT3/4, TSPY and $\beta$-catenin as biological markers for gonadoblastoma formation and malignant germ cell tumor development in dysgenetic gonads. Dis Markers 2013;34:419-424.

48 Som A, Wen S, Tu SM: Stem cell origin of testicular seminoma. Clin Genitourin Cancer 2013;11:489-494.

49 Sharpe RM, McKinnell C, Kivlin C, Fisher JS: Proliferation and functional maturation of Sertoli cells, and their relevance to disorders of testis function in adulthood. Reproduction 2003;125:769-784.

50 Sharpe RM, Skakkebaek NE: Testicular dysgenesis syndrome: mechanistic insights and potential new downstream effects. Fertil Steril 2008;89:e33-e38.

51 Hess RA, Cooke PS, Hofmann MC, Murphy KM: Mechanistic insights into the regulation of the spermatogonial stem cell niche. Cell Cycle 2006;5:1164-1170.

52 Rohozinski J, Bishop CE: The mouse juvenile spermatogonial depletion ( $j$ sd) phenotype is due to a mutation in the $\mathrm{X}$-derived retrogene, $m U t p 14 b$. Proc Natl Acad Sci USA 2004;101 11695-11700.
53 Beamer WG, Cunliffe-Beamer TL, Shultz KL, Langley SH, Roderick TH: Juvenile spermatogonial depletion ( $j s d$ ): a genetic defect of germ cell proliferations of male mice. Biol Reprod 1988;38:899-908.

54 Wistuba J, Schlatt S: Transgenic mouse models and germ cell transplantation: two excellent tools for the analysis of genes regulating male fertility. Mol Genet Metab 2002;77:61-67.

55 Xu EY, Lee DF, Klebes A, Turek PJ, Kornberg TB, Reijo Pera RA: Human boule gene rescues meiotic defects in infertile flies. Hum Mol Genet 2003;12:169-175.

-56 Reijo R, Lee TY, Salo P, Alagappan R, Brown LG, Rosenberg M, Rozen S, Jaffe T, Straus D, Hovatta $\mathrm{O}$, et al: Diverse spermatogenic defects in humans caused by Y chromosome deletions encompassing a novel RNA-binding protein gene. Nat Genet 1995;10:383-393.

57 Luetjens CM, Xu EY, Rejo Pera RA, Kamischke A, Nieschlag E, Gromoll J: Association of meiotic arrest with lack of boule protein expression in infertile men. J Clin Endocrinol Metab 2004;89:1926-1933.

58 Dann CT, Alvarado AL, Hammer RE, Garbers DL: Heritable and stable gene knockdown in rats. Proc Natl Acad Sci USA 2006; 103:11246-11251.

59 Blendy JA, Kaestner KH, Weinbauer GF, Nieschlag E, Schutz G: Severe impairment of spermatogenesis in mice lacking the CREM gene. Nature 1996;380:162-165.

60 Meachem SJ, Nieschlag E, Simoni M: Inhibin $B$ in male reproduction: pathophysiology and clinical relevance. Eur J Endocrinol 2001;145: 561-571.

-61 Andersson AM, Toppari J, Haavisto AM, Petersen JH, Simell T, Simell O, Skakkebaek NE: Longitudinal reproductive hormone profiles in infants: peak of inhibin B levels in infant boys exceeds levels in adult men. J Clin Endocrinol Metab 1998;83:675-681.

62 Andersson AM, Juul A, Petersen JH, Müller J, Groome NP, Skakkebaek NE: Serum inhibin $B$ in healthy pubertal and adolescent boys: relation to age, stage of puberty, and folliclestimulating hormone, luteinizing hormone, testosterone, and estradiol levels. J Clin Endocrinol Metab 1997;82:3976-3981.

63 Mackay S: Gonadal development in mammals at the cellular and molecular levels. Int Rev Cytol 2000;200:47-99.

-64 Dennis NA, Houghton LA, Jones GT, van Rij AM, Morgan K, McLennan IS: The level of serum anti-Müllerian hormone correlates with vitamin D status in men and women but not in boys. J Clin Endocrinol Metab 2012;97: 2450-2455.

65 Kolon TF, Patel RP, Huff DS: Cryptorchidism: diagnosis, treatment, and long-term prognosis. Urol Clin North Am 2004;31:469480, viii-ix.

-66 Wilkerson ML, Bartone FF, Fox L, Hadziselimovic F: Fertility potential: a comparison of intra-abdominal and intracanalicular testes by age groups in children. Horm Res 2001;55: 18-20. 
67 Kollin C, Stukenborg JB, Nurmio M, Sundqvist E, Gustafsson T, Söder O, Toppari J, Nordenskjöld A, Ritzén EM: Boys with undescended testes: endocrine, volumetric and morphometric studies on testicular function before and after orchidopexy at nine months or three years of age. J Clin Endocrinol Metab 2012;97:4588-4595.

-68 Jarvi K, Lo K, Fischer A, Grantmyre J, Zini A, Chow V, Mak V: CUA guideline: the workup of azoospermic males. Can Urol Assoc J 2010; 4:163-167.

69 Hadziselimovic F, Herzog B: The importance of both an early orchidopexy and germ cell maturation for fertility. Lancet 2001;358: 1156-1157.

70 Hadziselimovic F: Cryptorchidism, its impact on male fertility. Eur Urol 2002;41:121-123.

-71 Hauser R, Botchan A, Amit A, Ben Yosef D, Gamzu R, Paz G, Lessing JB, Yogev L, Yavetz $\mathrm{H}$ : Multiple testicular sampling in non-obstructive azoospermia: is it necessary? Hum Reprod 1998;13:3081-3085.

-72 Aksglaede L, Skakkebaek NE, Almstrup K, Juul A: Clinical and biological parameters in 166 boys, adolescents and adults with nonmosaic Klinefelter syndrome: a Copenhagen experience. Acta Paediatr 2011;100:793-806.

-73 Wikström AM, Raivio T, Hadziselimovic F, Wikström S, Tuuri T, Dunkel L: Klinefelter syndrome in adolescence: onset of puberty is associated with accelerated germ cell depletion. J Clin Endocrinol Metab 2004;89:22632270.

74 Wikström AM, Hoei-Hansen CE, Dunkel L, Rajpert-de Meyts E: Immunoexpression of androgen receptor and nine markers of maturation in the testes of adolescent boys with Klinefelter syndrome: evidence for degeneration of germ cells at the onset of meiosis. J Clin Endocrinol Metab 2007;92:714-719.

-75 Laron Z, Dickerman Z, Zamir R, Galatzer A: Paternity in Klinefelter's syndrome: a case report. Arch Androl 1982;8:149-151.

-76 Terzoli G, Lalatta F, Lobbiani A, Simoni G, Colucci G: Fertility in a 47,XXY patient: assessment of biological paternity by deoxyribonucleic acid fingerprinting. Fertil Steril 1992;58:821-822.

77 Damani MN, Mittal R, Oates RD: Testicular tissue extraction in a young male with $47, \mathrm{XXY}$ Klinefelter's syndrome: potential strategy for preservation of fertility. Fertil Steril 2001;76: 1054-1056.
78 van Saen D, Gies I, de Schepper J, Tournaye $\mathrm{H}$, Goossens E: Can pubertal boys with Klinefelter syndrome benefit from spermatogonial stem cell banking? Hum Reprod 2012;27: 323-330.

79 van Saen D, Tournaye H, Goossens E: Presence of spermatogonia in $47, \mathrm{XXY}$ men with no spermatozoa recovered after testicular sperm extraction. Fertil Steril 2012;97:319323.

80 Ramasamy R, Ricci JA, Palermo GD, Gosden LV, Rosenwaks Z, Schlegel PN: Successful fertility treatment for Klinefelter's syndrome. J Urol 2009;182:1108-1113.

81 Radford J: Restoration of fertility after treatment for cancer. Horm Res 2003;59(suppl 1):21-23.

82 Sousa M, Cremades N, Alves C, Silva J, Barros A: Developmental potential of human spermatogenic cells co-cultured with Sertoli cells. Hum Reprod 2002;17:161-172.

83 Cremades N, Bernabeu R, Barros A, Sousa M: In-vitro maturation of round spermatids using co-culture on Vero cells. Hum Reprod 1999;14:1287-1293.

84 Stukenborg JB, Wistuba J, Luetjens CM, Elhija MA, Huleihel M, Lunenfeld E, Gromoll J, Nieschlag E, Schlatt S: Coculture of spermatogonia with somatic cells in a novel three-dimensional soft-agar-culture-system. J Androl 2008;29:312-329.

85 Stukenborg JB, Schlatt S, Simoni M, Yeung $\mathrm{CH}$, Elhija MA, Luetjens CM, Huleihel M, Wistuba J: New horizons for in vitro spermatogenesis? An update on novel three-dimensional culture systems as tools for meiotic and post-meiotic differentiation of testicular germ cells. Mol Hum Reprod 2009; 15: 521-529.

86 Sato T, Katagiri K, Gohbara A, Inoue K, Ogonuki N, Ogura A, Kubota Y, Ogawa T: In vitro production of functional sperm in cultured neonatal mouse testes. Nature 2011;471:504507.

87 Sato T, Yokonishi T, Komeya M, Katagiri K, Kubota Y, Matoba S, Ogonuki N, Ogura A, Yoshida S, Ogawa T: Testis tissue explantation cures spermatogenic failure in c-Kit ligand mutant mice. Proc Natl Acad Sci USA 2012;109:16934-16938.
88 Kjartansdóttir KR, Gabrielsen A, Reda A, Söder O, Bergström-Tengzelius R, Andersen CY, Hovatta O, Stukenborg JB, Fedder J: Differentiation of stem cells upon deprivation of exogenous FGF2: a general approach to study spontaneous differentiation of hESCs in vitro. Syst Biol Reprod Med 2012;58:330-338.

89 Panula S, Medrano JV, Kee K, Bergström R, Nguyen HN, Byers B, Wilson KD, Wu JC, Simon C, Hovatta O, Reijo Pera RA: Human germ cell differentiation from fetal- and adult-derived induced pluripotent stem cells. Hum Mol Genet 2011;20:752-762.

$\$ 90$ Park TS, Galic Z, Conway AE, Lindgren A, van Handel BJ, Magnusson M, Richter L, Teitell MA, Mikkola HK, Lowry WE, Plath K, Clark AT: Derivation of primordial germ cells from human embryonic and induced pluripotent stem cells is significantly improved by coculture with human fetal gonadal cells. Stem Cells 2009;27:783-795

91 Takahashi K, Tanabe K, Ohnuki M, Narita M, Ichisaka T, Tomoda K, Yamanaka S: Induction of pluripotent stem cells from adult human fibroblasts by defined factors. Cell 2007; 131:861-872.

92 Bongso A, Fong CY, Ng SC, Ratnam S: Isolation and culture of inner cell mass cells from human blastocysts. Hum Reprod 1994;9: 2110-2117.

-93 Thomson JA, Itskovitz-Eldor J, Shapiro SS, Waknitz MA, Swiergiel JJ, Marshall VS, Jones JM: Embryonic stem cell lines derived from human blastocysts. Science 1998;282:11451147.

94 Gondos B, Hobel CJ: Ultrastructure of germ cell development in the human fetal testis. Z Zellforsch Mikrosk Anat 1971;119:1-20.

$>95$ Hadziselimovic F: Cryptorchidism. Heidelberg/New York, Springer, 1977.

96 Fukuda T, Hedinger C, Groscurth P: Ultrastructure of developing germ cells in the fetal human testis. Cell Tissue Res 1975;161:55-70.

-97 Niemi M, Ikonen M: Primordial germ cells in foetal and postnatal human testis. Ann Med Exp Biol Fenn 1965;43:23-28.

98 Paniagua R, Nistal M, Amat P, Rodriguez MC: Ultrastructural observations on nucleoli and related structures during human spermatogenesis. Anat Embryol 1986;174:301306.

99 Rowley MJ, Berlin JD, Heller CG: The ultrastructure of four types of human spermatogonia. Z Zellforsch Mikrosk Anat 1971;112: 139-157. 